\title{
Understanding the formation and actions of Eurosceptic groups in the European Parliament: pragmatism, principles and publicity
}

Forthcoming in Government and Opposition

Richard Whitaker (rcw11@ leicester.ac.uk) and

Philip Lynch (ㄴLL3@leicester.ac.uk)

Department of Politics and International Relations

University of Leicester

University Road

Leicester LE1 7RH

\section{Abstract}

This article assesses why Eurosceptic national parties form groups in the European Parliament (EP) and examines in what ways two of these groups - the European Conservatives and Reformists (ECR) and Europe of Freedom and Democracy (EFD) operate in the EP. It draws on interviews with politicians and group officials, roll-call votes and expert judgement data. We look at the group formation process with a focus on the British Conservatives and UK Independence Party (UKIP) and find that the ECR was created with a mixture of policy-seeking and party management aims. UKIP's interest in the EFD is largely on the basis of distinctive practical advantages, such as resources for political campaigns. We provide evidence that hard Eurosceptic and regionalist niche parties in the EP struggle to agree with each other in roll-call votes on a range of subjects. Finally, we show that the hard and soft Eurosceptic parties studied here go about policy-seeking in different ways in the EP in line with their differing principles about the integration process.

Key words: European Parliament, party groups, Euroscepticism, niche parties, UKIP, Conservatives

\section{Acknowledgements}

We thank the reviewers for helpful comments. We are grateful to the MEPs and party group officials who kindly granted us interviews. We thank Simon Hix for providing raw roll-call vote data from the seventh term, Gemma Loomes for invaluable research assistance and Simona Guerra for advice on the Lega Nord. This article draws partly on research funded by the Leverhulme Trust under grant number F/00 212/AD. 


\section{Understanding the formation and actions of Eurosceptic groups in the European Parliament: pragmatism, principles and publicity}

Eurosceptics have long been present in the European Parliament (EP) on both the left and right. But in recent years, they have become more clearly organized within the EP's group structure, particularly in the form of the soft Eurosceptic European Conservatives and Reformists (ECR) group formed after the 2009 EP elections. Soft Eurosceptic parties do not oppose the European Union (EU) in principle but are against further European integration (Taggart and Szczerbiack 2008: 248). Hard Eurosceptics, favouring withdrawal from the EU, are scattered across groups and the non-attached members in a less coherent fashion but their profile has been raised particularly by the leader of the UK Independence Party (UKIP) and co-President of the Europe of Freedom and Democracy (EFD) group, Nigel Farage. Hard Eurosceptics face tricky decisions about how far to engage in an institution that they oppose but which can also bring them rewards in terms of information on EU policy developments, publicity and financial benefits useful for promoting their cause. While we know much about what happens inside the EP, there has been limited research specifically on how Eurosceptics go about operating within it (for welcome exceptions to this see Benedetto 2008; Brack 2012, 2013; Startin 2010), an interesting question in the light of the conflicting pressures they face and given the range of Euroscepticism represented in the EP from those favouring reform to those wanting to abolish the institution itself.

Scholars have assessed reasons for forming party groups in the European Parliament (e.g. Hix et al. 2007, McElroy and Benoit 2010, Bressanelli 2012) but not all of the proposed motivations apply to national parties that oppose either many aspects of European integration or their country's membership of the EU. For these national parties, group formation may be motivated by a desire for publicity and information about EU policies, or a concern with national party management. This article contributes to our understanding of group formation and group action in the EP by assessing, with a focus on UKIP and the British Conservatives, why Eurosceptic national parties form groups and by examining in what ways and how effectively two of these groups - the ECR and EFD - operate in the European Parliament.

More specifically, we assess non-policy related reasons for forming a party group in the EP. We go on to ask how Eurosceptic groups use the European Parliament and to what degree they act as a coherent force. We use expert judgement data on party positions (Bakker et al. 
2012), roll-call votes from the seventh term of the EP and data from the VoteWatch Europe website (www.votewatch.eu). Our discussion of group formation and part of our analysis of activities in the EP draw on 40 non-attributable interviews conducted during the period 200912 by the authors with ECR (five) and EFD (four) group staff, Conservative MEPs (15), UKIP MEPs (eight), one Czech Civic Democrat MEP, UKIP officials (three), one Conservative MP, one Conservative official and two senior EP officials. The bias towards British MEPs here means that we look at group formation mainly through a UK lens although interviews with staff from both groups provide a broader base of information.

These two party groups are not, of course, the only places in which Eurosceptic MEPs can be found. The European United Left/Nordic Green Left (GUE/NGL) group houses national parties from the left of the ideological spectrum, many, although by no means all of whom, are Eurosceptic. The Union for a European of the Nations (UEN) group, which existed in the fifth and sixth EP terms, might be seen as similar to the ECR in that it included some governing parties and was made up partly of Eurosceptics. But it differed from the ECR because it also housed more pro-integrationist parties such as Fianna Fáil, and did not aim primarily to be a Eurosceptic group (Benedetto 2008). While the UEN's charter 'avoid[ed] language that is overtly Eurosceptic' (Benedetto 2008: 138), the charters of the EFD and ECR emphasise sovereign nation states in Europe and opposition to either a 'European superstate' (EFD) or 'EU federalism' (ECR). These two groups stand out from others in that a Eurosceptic stance, broadly defined, is one of their defining features and was a motivation for establishing the group, something we discuss in more detail below.

\section{Theories of group formation and activities in the European Parliament}

Research on parties in the EP suggests a number of motivations for forming party groups. McElroy and Benoit (2010) test a policy congruence theory in which national parties will join groups that are closest to their own position on their most salient policy dimensions. Their results show that this explains the composition of most of the EP groups well. Nonetheless, they note that there are likely to be some non-policy factors at play in some national parties' decisions (McElroy and Benoit 2010: 396-7), something they do not explore. In a further analysis based on more recent expert surveys of EP party group positions they show that the theory holds up well for groups in the 2009-14 term (McElroy and Benoit 2011). Nevertheless, we hypothesise that this approach will much better explain the ECR than the 
EFD on the basis that, as discussed later, the former was set up to bring together centre-right parties who agree on the need to reform the EU in a way that protects the sovereignty of member states. By contrast, of the two national parties that make up the bulk of the EFD, one is hard Eurosceptic (UKIP) and the other soft Eurosceptic (Lega Nord). Given this difference, the policy congruence approach is unlikely to apply to this group, at least not on the assumption that the European integration dimension is the most salient to parties in the group, something we investigate below. In addition to this, achieving policy congruence might be made more difficult for the ECR because the larger groups had gained some national parties that the ECR might have favoured. The Finnish Centre Party MEP Hannu Takkula, for instance, joined the ECR at its beginning but left it two days later under pressure from his party back home to remain within the Alliance of Liberals and Democrats for Europe (ALDE) (EurActiv 2009). For the EFD the problems are worse with its founders having to choose partly from among those rejected by the ECR while avoiding parties with whom, for domestic reasons, they do not want to associate, such as the British National Party. These problems should be viewed in the light of the EP's Rules of Procedure (Rule 30), which require party groups to consist of at least 25 MEPs drawn from one quarter of the member states, which amounts to seven in the 2009-14 term.

Moving on from policy congruence theory, Bressanelli (2012) theorized that national parties may be attracted to party groups for pragmatic reasons. These include the resources allocated to groups and the opportunity for gaining influential committee positions and rapporteurships in the EP. These incentives are particularly significant in the case of the larger groups because of the EP's distribution of positions and resources in proportion to group size. Party groups themselves are also motivated to attract large national parties in order to increase their size and gain the financial, staffing and office benefits that follow from growth. Bressanelli's results show that the bigger the national party, the more likely they are to join a larger group over a smaller one. But interestingly Bressanelli (2012: 746) found rather more mixed results for the ECR and EFD indicating that other factors are at work in explaining the composition of these groups.

What might these factors be? Some of the answer lies in theories of party behaviour. Strøm (1990) sets out three types of this: office-, policy- and vote-seeking. Applied to national parties in the EP, Bressanelli's (2012) argument about pragmatic motivations for joining larger groups fits with office-seeking behaviour. The policy congruence approach fits with 
policy-seeking priorities. However, vote-seeking behaviour is only likely to affect national parties' choice of EP party group if this choice is salient among their voters (Maurer et al. 2008: 249). If the issue is salient among a party's parliamentarians and activists, then group choice may be made on the basis of party management (Lynch and Whitaker 2008). In either case, this might lead to a choice that does not maximize the possibility of policy influence.

Once Eurosceptic groups have been formed, how can we expect them to behave in the EP? Some insight into how hard Eurosceptic groups and national parties within them might act comes from work on niche parties. While there is debate as to their definition, we start from Wagner's (2012: 847) definition of parties that 'compete primarily on a small number of noneconomic issues'. This means they include regionalist, radical right, green and anti-EU parties. Jensen and Spoon's (2010) research on this suggests that niche parties in the EP will act differently to their mainstream counterparts. These parties' focus on national or regional autonomy and identity means that such concerns may be particularly important for them when deciding how to vote in the EP. Such parties will be less likely to compromise on policy positions than their mainstream counterparts on the basis that they risk losing their core support if they moderate policy (Adams et al. 2006), and because the organization of niche parties tends to favour influence for activists (Ezrow et al. 2011; Dumont and Bäck 2006). Jensen and Spoon (2010: 188) also find that views on European integration differ between sub-types of niche party. These various points lead us to hypothesise that there will be divisions within the EFD group as its two largest national parties include a regionalist party (the Lega Nord) and an anti-EU one (UKIP), as well as the Mouvement Pour la France (MPF), also classified as an anti-EU niche party by Jensen and Spoon (2010).

Müller and Strøm's (1999: 17) approach suggests that when party organization favours activist influence - as in many niche parties - we are more likely to see policy-seeking rather than office- or vote-seeking behaviour. How this affects a party's approach to the EP may depend on their policy goals. For hard Eurosceptic parties, which seek their country's withdrawal from the EU, we hypothesise that policy-seeking behaviour is less likely to be focused on legislative work in the EP as this is not a venue in which decisions about leaving or remaining in the EU are made. For these parties, in contrast to expectations about mainstream party groups in the literature on group formation, we expect group membership to be used for publicity-seeking behaviour, primarily speaking in (high profile) plenary sessions and channelling the financial resources that flow from being in a group, into political 
campaigns. On this point, Startin (2010) shows how, when establishing the short-lived Independence, Tradition and Sovereignty group in 2007, radical right MEPs were motivated by the significant financial and practical advantages they felt would follow from this. Alternatively, for parties that favour reform of the EU - in our case, the ECR group - we expect policy-seeking behaviour to include attempts to influence the EU's legislative process (Benedetto 2008) such as by trying to build coalitions with other party groups with the aim of affecting the outcome of votes. As the two largest parties in the EFD differ in terms of their Euroscepticism, we hypothesise that there will be differences in their behaviour with the Lega Nord involving themselves much more in the details of the EP's legislative activities.

We test these expectations by looking at several aspects of Eurosceptic parties' approach to operating in the EP: forming groups, voting and engagement with legislative processes. In the next section we look briefly at the first of these, mainly in relation to the British Conservatives in the ECR group and UKIP in the EFD. These constitute the largest national party in each of the two groups and allow us to compare the motivations for group formation of a soft and hard Eurosceptic party. Concentrating on these two parties in understanding group formation also allows us to look in detail at the motivations and consequences of putting together these two groups for the largest member of each. Our expectations concerning UKIP's motivations for group formation could equally apply to their role in the EFD's predecessor, Independence/Democracy (I/D), although we lack the space and data to examine the formation and actions of that group here. While UKIP were also part of I/D's forerunner in the fifth term, Europe of Democracies and Diversities (EDD), they only had three MEPs at the time, meaning they were in a rather weaker position with regard to group formation.

\section{Forming the ECR and EFD groups}

What factors explain the formation of the ECR and EFD and are these factors specific to groups that are Eurosceptic in outlook? This section answers these questions, drawing heavily on interviews conducted by the authors.

The British Conservatives and the ECR: principles over influence? 
The ECR was born in July 2009 after a long process of debate in the British Conservative party about its EP group membership. While we do not have space to describe this in detail here, the Conservatives' decision to leave the European People's Party-European Democrats (EPP-ED) group related to the their shift to a soft Eurosceptic position during the 1990s (Webb 2000: 185). This led some Conservative parliamentarians and activists to argue that they had moved away from the EPP-ED's more pro-integration stance. The process was problematic because Conservative MEPs were divided over the issue (Lynch and Whitaker 2008) and eventual group members, the Czech Civic Democrats (ODS) and Polish Law and Justice party (PiS), were not prepared to move in 2006 when the Conservatives were making their initial attempts to establish a new group.

How does the formation of this group fit with the party goals set out earlier? The evidence is mixed as to whether the primary motivation for the Conservatives and ODS to leave the EPPED and join the ECR was office-seeking behaviour. The Conservatives lost the opportunity to lead the most legislatively active committees, such as Environment for which they held the chair in the fifth EP term (1999-2004) when part of the EPP-ED. The ODS had also chaired this committee in the sixth term (2004-9), when part of the EPP-ED group. However, following the formation of the ECR, the Conservatives gained the chair of the Internal Market committee, a subject of particular significance for the party. A further positive point made by many Conservative interviewees was that compared with the EPP-ED, the ECR offered a greater chance of securing positions at the group level, specifically group coordinators on committees and shadow rapporteurships, the numbers of which do not vary by group size. In addition, given their electoral performance in 2009, the UK Conservatives would have found themselves as only the fifth largest national party contingent in the EPP$\mathrm{ED}$, reducing their chances of winning influential posts.

Second, there is some evidence that the formation of the group represents policy-seeking behaviour. Joining the ECR over a larger group, would seem inconsistent with an attempt to improve a party's ability to influence the EP's legislative outputs (Maurer et al. 2008). However, if policy influence requires groups to be cohesive then national parties will also need to consider the policy preferences of others. The founding principles of the ECR, expressed in the Prague Declaration, suggest that agreement on an approach to European integration provides a coherent basis for the group. As one Conservative MEP put it, "it has given the EP something of an official opposition ... this is the first time that a group of 
governing or potentially governing parties have got together to offer an alternative view of the EU'. ${ }^{1}$ This explanation is consistent with McElroy and Benoit's (2010) policy congruence theory which we examine in more detail later.

Third, for the Conservatives, there is little evidence that forming the ECR represents voteseeking behaviour because the EU, and by implication, the party's choice of group in the EP, was not a salient issue among Conservative voters at the general election prior to them leaving the EPP-ED. According to the British Election Study's post-campaign internet survey, ${ }^{2}$ only 4.4 per cent of Conservative voters saw Britain's relations with the EU or the Euro as the 'most important issue' in the 2005 general election campaign and this figure was only 0.7 per cent in the equivalent survey in $2010 .{ }^{3}$ However, the question of the party's group membership in the EP was an issue in the 2005 leadership election with Cameron seeking votes by promising to take his party out of the EPP-ED (Lynch and Whitaker 2008).

Fourth, in addition to policy aims, the decision to form a new group for the Conservatives seems to have been driven partly by the need to manage divisions within the party over European integration. Taking the Conservatives out of the EPP-ED group was something Cameron could do without being in government, assuaging Conservative Eurosceptics and allowing the party, in Cameron's own words, to be 'good neighbours rather than unhappy tenants' (Independent 2009) of the EPP-ED. Nevertheless, creating a group generated new party management problems because not all MEPs were happy with the decision, as is clear from a Conservative interviewee's comment that 'we [now] have independence but no real influence'. ${ }^{4}$ In addition, the hostile reaction in some of the UK media to some of the Conservatives' partners in the ECR (Bale et al. 2010) demonstrated the problems of meeting the criteria for group formation in the EP while managing likely domestic media responses.

\section{UKIP's role in forming the EFD: publicity and pragmatism}

The EFD has its origins in the Independence/Democracy group of the sixth EP term and the EDD during the fifth, both of which were primarily Eurosceptic groups but which included parties not only from the right but also from the left of the spectrum, principally the Danish June Movement. The largest national party within the EFD is UKIP, a hard Eurosceptic party advocating withdrawal of the UK from the EU. If UKIP sees the EP as an institution of which the UK should not be a part, what is its rationale for being part of and providing co-leadership 
of a group? In interviews with EFD group staff and UKIP MEPs, a number of motivations were expressed. Among the most prominent was speaking time in plenary sessions, particularly for the group's co-president Nigel Farage. As one UKIP MEP put it 'If you think of all [Nigel Farage's] memorable performances in the European Parliament ... it's all been done with speaking time in the plenary' ${ }^{5}$ On the basis of the EP's Rules of Procedure (Rule 149) groups are at some advantage regarding speaking time compared to non-attached members and this advantage increases with group size. A UKIP interviewee pointed to the publicity the party gains outside of the UK from Farage's EP performances. ${ }^{6}$ In this respect, the existence of the group helps UKIP to promote the Eurosceptic cause and to develop an opposition within the EP.

A second reason for being part of a group given by interviewees was the financial benefits and staffing allocations provided for research and administrative purposes. The financial resources are seen as important partly, as one interviewee put it, because they would otherwise 'go to pro-federalist organisations ${ }^{7}$ but also because they allow the EFD to fund political campaigns such as those against the Lisbon Treaty in the second Irish referendum on this $^{8}$ and in Ireland's referendum on the Fiscal Compact. The provision of research staff means that MEPs have experts available to them who can advise on how the EP works and on the details of policy proposals. For UKIP, this provides fuel for campaigns at the national level. Some interviewees referred to other office benefits, principally the allocation of places on the EP's committees, where much of its legislative work is carried out. For instance, some UKIP MEPs pointed to the political capital they can gain from being able to question senior figures during committee hearings. This feeds into their aims of achieving publicity and acquiring information on EU legislation.

Despite these benefits, several interviewees gave a sense that their group was formed reluctantly. A UKIP MEP explained that because of the procedural privileges given to groups in the EP, 'we're forced into [forming a group]. The key thing is, it's a group not a party...it is practically driven, not principled'. ${ }^{9}$ Indeed, events following the formation of the EFD demonstrated differences within the UKIP delegation over the EFD and its composition. For instance, two UKIP MEPs (Colman and Nattrass) left the EFD due to disagreements with the group but were permitted to remain in UKIP. ${ }^{10}$ To a degree, this reflected disagreements within UKIP about how far to involve itself in the EP's structures. 
This discussion suggests significant differences in the motivations of UKIP and the Conservatives in forming groups in the EP with UKIP reluctantly forming a group in order to gain specific practical advantages while policy-seeking behaviour and party management explain the Conservatives' decision. We can understand further the basis of these two groups beyond a purely British focus by looking next at intragroup ideological diversity and asking how far the ECR is ideologically cohesive, as we would expect if its formation represents policy-seeking behaviour, and comparing this with the range of views within the EFD group.

\section{Ideological diversity in EP groups: party positions and voting cohesion}

This section looks first at the ideological diversity of EP groups and then examines their cohesion in roll-call votes. On the basis of the preceding discussion, we expect the policy congruence approach (McElroy and Benoit 2010) to apply to the ECR, such that it is cohesive in policy dimensions that are of salience to its national parties. For the EFD we expect lower ideological cohesion on the basis that the group includes different types of niche parties and was formed for more practical reasons.

We examine this using national parties' positions on the left-right and European integration scales from the 2010 Chapel Hill expert survey (Bakker et al. 2012). The 2010 wave of this survey is the closest to the time at which the ECR and EFD groups were formed and includes all member states except Cyprus, Luxembourg and Malta. The vast majority of parties represented within the seven party groups formed after the 2009 EP elections are included. In all but two cases, parties missing from the data were made up of only one or two MEPs. ${ }^{11}$

We adopt the same approach to calculating ideological diversity, albeit with different data, as Hix et al. (2005: 224), in which parties are weighted by size. We first calculated the weighted mean position of party group $M_{i}$ for the left-right dimension as follows:

$$
M_{i}=\sum_{j=1}^{n_{i}} P_{j} S_{j i}
$$


where $P_{j}$ is the left-right position of national party $j$ from the Chapel Hill 2010 survey, $S_{j i}$ is the proportion of party group $i$ made up by national party $j$. The same calculation was made, using the EU position of each national party. ${ }^{12}$ We then calculated the ideological diversity of each group (Hix et al. 2005: 224) for left-right and EU dimensions as follows:

$$
\text { Ideological diversity (on left }- \text { right scale })_{i}=\sum_{j=1}^{n_{i}}\left|P_{j}-M_{i}\right| S_{j i}
$$

where $M_{i}$ is the weighted mean position of party group $i$ on the left-right dimension, $P_{j}$ is the left-right position of national party $j$ and $S_{j i}$ is the proportion of party group $i$ made up by national party $j$. The same calculation was made for the European integration dimension. The results are in Table 1 where higher scores indicate more diversity.

[Table 1 about here]

Interestingly, the EFD compares well with the European People's Party (EPP), ALDE and Greens/European Free Alliance (G/EFA) groups on the left-right scale of ideological diversity. This is consistent with McElory and Benoit's (2011: 162) results that show a narrow range of views on this dimension using different data. This may be partly a result of the comparatively small number of national parties within the EFD but also suggests a degree of policy congruence on this dimension, particularly in contrast with the group's predecessor, Independence/Democracy, which included some MEPs from the left. Nevertheless, Table 1 also shows that the EFD is the most ideologically diverse group on the EU integration scale. This does not fit with the policy congruence model given the salience of this issue to the group. These findings are consistent with EFD interviewees' comments of which the following was typical: 'We only have loose things in common and we don't share a manifesto'. ${ }^{13}$ While the Lega Nord is a Eurosceptic party, its position contrasts with that of UKIP. It shifted from a pro-integration view during the 1990s to a far more critical stance after 1998 particularly with regard to economic and monetary union, the common agricultural policy and EU state aid policies (Chari et al. 2004). Nonetheless, it voted in favour of the Nice and Lisbon treaties (Bartlett et al. 2012) and its scores in the Chapel Hill data differ substantially from UKIP's on several areas of EU activity including EU cohesion policy, 
where it is placed at 4.3, compared with 1.2 for UKIP on a seven point scale with higher values representing greater support for this policy.

The diversity within the ECR is considerably more limited on both dimensions and the group compares favourably with others on both scales. This is due to the similarity of positions among the three largest contingents in the group, the Conservatives, PiS and ODS. Overall, the results suggest that policy congruence was a major factor bringing together the parties that make up the ECR. In contrast, policy similarities on European integration were not the primary motivation for forming the EFD group although it is comparatively cohesive in leftright terms.

Understanding the ideological diversity within groups can only tell us so much about how effective groups are at achieving their aims in the EP. The next step is to review how far these two groups act as a cohesive force by examining their behaviour in roll-call votes. As Hix et al. (2007: 101-2) have shown, ideological fractionalisation did not affect group cohesion in roll-call votes for the period 1979-2004, suggesting that cohesion is not based entirely on preferences. They theorize that larger groups will be more cohesive because they are more likely to influence policy outcomes and therefore have more at stake in EP votes (Hix et al. 2007: 101). Our earlier discussion of niche parties suggested we should expect a lower propensity for them to compromise with others to achieve group positions. We can assess this in the case of national parties in the EFD. We use data from the VoteWatch Europe website (www.votewatch.eu). Then we analyse coalition patterns among national parties within the two groups based on all roll-call votes from July 2009-December 2010.

VoteWatch Europe data on roll-call votes from the beginning of the seventh term (July 2009) up to March 2013 show that the EFD is the least cohesive party group, in line with our expectations. The Index of Agreement (Hix et al. 2007), by which VoteWatch measure cohesion, can range from zero, when a group is evenly split among the options of 'yes', 'no' and 'abstain', and 100, when the entire party group votes the same way. The EFD stands out with a score of 49.7 compared with scores in the 90s for all other groups except ALDE (88.9), GUE/NGL (79.2) and ECR at 86.4. ${ }^{14}$ The high score for the G/EFA group (94.6) which includes two types of niche party (green and regionalist) is out of line with the suggestion that niche parties in general will struggle to agree with each other in a transnational group setting. But our expectation of low cohesion in the EFD, on the basis that 
its two largest components are a hard Eurosceptic and a regionalist party, is borne out. This is not surprising in the light of comments made by EFD party group staff that there is no formal whip for the whole group ${ }^{15}$ and that 'there is an acknowledgement ... that every party is free to espouse its own views as long as these are not racist or anti-democratic'. ${ }^{16}$ Furthermore, the greens in the EP have a much longer history as a group and as an extra-parliamentary organisation through the European Federation of Green Parties (Hanley 2008: 169). The ECR's cohesion score is much closer than the EFD's to the largest groups, in line with our expectations.

[Table 2 about here]

Next we turn to what underpins the cohesion, or lack of it, in these two groups. Table 2 shows coalition patterns among the national parties making up the EFD group. The table is based on all roll calls from July 2009 - December 2010. Figures show the percentage of votes on which a majority of one national party voted with a majority of another. Crucially, for the group's cohesion, majorities of the two largest parties, UKIP and the Lega Nord (LN), both of which can be classified as niche parties, only vote with each other in about one in three votes. A number of parties including the LN, the Popular Orthodox Rally (LAOS), the Slovak National Party and the True Finns are more likely to vote with each other (Table 2). This makes sense in terms of the softer Euroscepticism of these parties compared with UKIP. ${ }^{17}$

[Table 3 about here]

Table 3 shows equivalent figures for the ECR group, which are much higher than those for the EFD, as would be expected on the basis of the group's index of agreement scores. Of the group's three main parties, the Conservatives and ODS vote with each other in about nine out of ten votes, slightly more than either of them does with PiS.

These figures cover votes on a range of topics and therefore might mask differences within the groups over particular policy areas. Given the presence of niche parties in the EFD we expect differences on issues that might have national or regional repercussions. The differing types of Euroscepticism between UKIP and the LN also lead us to expect disagreement between the two. We consider roll-call votes from the same dataset under three types of policy, allowing us to test for economic left-right, national or regional and integration-based 
differences: regulation of the single market in the form of environment and public health policy (156 votes), distributive policies measured via votes on the budget (167 votes) and agricultural policy (67 votes), and integration issues, assessed through votes on constitutional and inter-institutional matters (40 votes).

In the votes on environmental policy, majorities of national parties voted the same way in more than nine out of ten votes for most combinations in the ECR. In the EFD, majorities in the two largest parties, UKIP and the LN, voted the same way in only around one fifth of votes (20.8 per cent). In the 167 roll-call votes on budgetary matters, UKIP and the LN managed a slightly higher degree of similarity than in all votes with a score of 41.7 per cent. In the ECR, the Conservatives and ODS were largely together on 89.0 per cent with somewhat lower scores for the ODS and PiS (66.3 per cent) and Conservatives and PiS (69.3 per cent) indicating a degree of difference between the PiS and the other two largest parties in the group. In votes on agricultural policy, majorities within UKIP and the LN voted the same way on only 23.1 per cent of votes. In the ECR, compared with results for all roll-call votes in this period, there were greater differences between the PiS and the other two major parties with scores of 65.7 per cent for the ODS and PiS and 73.1 per cent for the Conservatives and PiS. This makes sense on the basis of the size of the agricultural sector in Poland combined with the lower level of support for farmers in the accession states compared with the EU15. In the 40 roll calls on constitutional affairs from July 2009 to December 2010, majorities of UKIP and LN MEPs voted together on less than a quarter of the votes (23.5 per cent), while figures for pairs of parties in the ECR are almost all in the 90s.

So while the EFD is commonly understood as a Eurosceptic group, on issues concerning EU integration and other areas of policy there are considerable differences in voting behaviour within it. This is consistent with our expectations based on the presence of hard Eurosceptic and regionalist niche parties within the group (UKIP, LN, MPF) and the differing types of Euroscepticism espoused by its two largest national parties. The ECR, by contrast has a cohesive core of national parties but which experience slightly higher levels of disagreement on distributive policies in the sample of roll-call votes used here. Given this contrast and our expectations about how hard and soft Eurosceptic parties might make use of the EP in different ways, the next section looks at how far and in what ways these groups, and some of the parties within them, take part in the EP's business. 


\section{(Dis)engaging with the EP's legislative and non-legislative business? ECR and EFD approaches}

Earlier we set out expectations that hard Eurosceptics will be largely reactive and/or engaged only for the purpose of gathering information to feed into campaigns. Soft Eurosceptics can be expected to take part in the policy-making process in an attempt to move policy closer to their ideal point. While other research has considered the actions of individual Eurosceptic MEPs (e.g. Brack 2012, 2013; Navarro 2012), here we focus on groups' and national parties' activities in the first half of the seventh term. We have space only to sketch some examples of these groups' approaches to the EP's activities, but they serve to indicate the variation between the two groups.

\section{ECR: attempting legislative influence}

On the basis of the Prague Declaration - the ECR's founding statement - we would expect this group to be engaged with policy-making in the EU in an attempt to make changes in line with its preferences for free enterprise, minimal regulation and the sovereignty of member states. Here, drawing on our interviews, we focus on the British Conservatives in the group although the approaches described are not exclusive to them. We should expect policyseeking Conservative MEPs to attempt influence in areas of concern to the party and its voters. We expect this to be particularly important for areas where the Conservatives differ from many in the EPP, such as on European integration and the regulation of financial services and protection of the City of London. Given that the allocation of positions in the EP is based on proportional representation of party groups, the ECR's place as the fifth largest group with around 7 per cent of the seats means that high profile legislative reports are unlikely to come their way. Conservatives used to working in the much larger EPP-ED have therefore had to be smarter about their approach to the EP's procedures. Interviewees pointed to two methods of attempting influence, first, making strategic use of own initiative reports, and second, attempts at building alliances with others where there is common ground.

Many of our interviewees referred to the use of own initiative reports (OIRs), particularly those defined in the EP's Rules of Procedure (Annex XVIII) as strategic, drawn up on the basis of items included in the Commission's annual legislative programme and therefore 
expected to be the subject of legislation in the near future, or implementation reports concerning the implementation and enforcement of EU laws. Data from the EP's Legislative Observatory for the first 3.5 years of the seventh term show the ECR received a roughly proportional share of OIRs. However, ECR group staff suggested the group is strategic about the reports it tries to win, aiming to gain them in areas where significant legislation is imminent. As one Conservative MEP put it, 'the own initiative route is a very good tool to set the legislative agenda down a path you would like it to go... it is easier to have a Commission document that starts in a good place so you can tweak it' ${ }^{18}$ Reports in the EP are distributed on the basis of a bidding process in which groups have points that they can spend and which are allocated to groups in proportion to their size. Non-legislative reports are easier to obtain for a smaller group as they cost fewer points than the legislative reports that follow. Interviewees explained that the Commission will sound out rapporteurs and shadow rapporteurs on OIRs covering topics about which they plan to legislate, giving an indication of how these reports are used by the Commission to measure opinion in the EP.

Two particular cases help to demonstrate this approach. First, an OIR on trading in financial instruments ${ }^{19}$ (2010/2075(INI)) was drawn up by Conservative MEP Kay Swinburne ahead of the Commission's plans to revise its Markets in Financial Instruments Directive (MiFID). Interviews with ECR group staff suggested that although compromises and changes were made, the OIR set the framework for what followed, ${ }^{20}$ known as MiFID II. In a media interview in February 2011, Swinburne described having seen how OIRs could be used to prepare the way for legislation that follows. She explained that MiFID II would be highly significant for the City of London and the UK economy and this was the reason for making sure the group won this OIR, which she hoped would 'shape the initial direction in which [the legislation] was going' (O'Hara 2011). The Commission's first draft of MiFID II proposed, among other things, tougher rules on high frequency trading (HFT), representing a development of calls for an assessment of the pros and cons of HFT in Swinburne's OIR (Spicer 2010). At the time of writing it is at first reading stage.

Second, an OIR on the implementation of the Professional Qualifications Directive (2011/2024(INI)) was drawn up by Emma McClarkin MEP ahead of Commission plans for legislation on this subject. Interviewees argued that the presence of an early warning mechanism about individuals' malpractice and a requirement for language testing in the Commission's subsequent legislative proposal, both of which were retained by the EP at first 
reading in committee ${ }^{21}$ (Stamatoukou 2013), are evidence that key points favoured by the ECR's rapporteur were taken on board.

In the second of these two cases, however, interviewees were careful to point out that there was broad support in the EP for much of the ECR's position, making it easier to ensure this was carried forward. In addition, due to a lack of support from the two largest party groups, the ECR did not get its way in the OIR on the need for a detailed impact assessment of the proposed 'professional card' - designed to ease professionals' movement around the EU prior to its introduction.

These caveats indicate the importance of building coalitions in the EP in order to influence outcomes. An example of coalition building cited by interviewees concerns the EU's most recent proposals on maternity leave. In March 2010, the EP's Women's Rights committee voted on the Commission's proposals to extend the length of maternity leave on full pay to 18 weeks. The committee supported raising this to 20 weeks but without the support of the ECR. This group demanded an impact assessment be carried out, to which the Commission agreed (Petitjean, 2010). This had the effect of delaying the legislative process and, according to ECR interviewees, enabled the group to build support from others in the EP including central and east European member states unhappy about the costs, as well as the UK Labour party, in government at the time, who reportedly favoured delaying the legislation until after the May 2010 UK general election. ${ }^{22}$ While the 20 weeks amendment was narrowly supported at first reading in October 2010, the legislation subsequently became stalled in the Council. This resulted, if not in a veto, then at least in an outcome favoured by the ECR.

Many interviewees also mentioned the 'single seat' issue as one on which the ECR had been proactive in seeking a coalition of support. This concerns the aim of ending the EP's trips to Strasbourg for plenary sessions 12 times each year. Among several votes on this issue, in an OIR on the Multiannual Financial Framework (2010/2211(INI)) for post-2013, MEPs held a roll-call vote on the EPP's proposal to remove a paragraph that referred to the 'significant savings that could be made in the European Parliament were to have a single seat' with the ECR on the winning side (353 votes against removing the paragraph, 282 in favour and 38 abstentions). Furthermore, against the wishes of the EPP, ${ }^{23}$ sufficiently widespread support was gained in the Conference of Presidents to permit an OIR on the EP seat issue 
(2012/2308(INI)) with the rapporteurship being shared between Conservative MEP Ashley Fox and G/EFA member, Gerald Häfner.

These cases demonstrate approaches used by Conservatives in their attempt at legislative influence in areas of significance for the party, such as the cost of the EP and the regulation of the single market insofar as it affects employers' costs and the City of London. But ECR group staff noted that influence over legislation affecting the latter was hard enough for the Conservatives when part of the EPP-ED due to differences with others in the group. In the ECR, the combination of what some described as a more difficult environment for Conservatives since Cameron's veto of a draft fiscal compact in 2011 and being the fifth largest group means that making a difference in the EP is not easy. VoteWatch Europe data show the group is on the losing side in a majority of roll calls in areas related to the European integration dimension, namely, constitutional affairs, the budget, budgetary control and the EP's rules. The ECR is also on the losing side most of the time in roll calls on issues of culture, economic and monetary affairs, and gender equality. This mixture of indirect influence in some areas and the experience of being on the losing side in others was summed up by one Conservative MEP explaining that the group is 'not an unmitigated disaster but not a runaway success either'. ${ }^{24}$

\section{EFD: limited engagement}

'It's like walking on a tightrope. I won't be voting for any EU legislation ... but it's not credible to go there and just object to everything'. UKIP MEP, 23/09/09.

We know from previous work on MEPs' roles that hard Eurosceptics take a range of approaches to the EP from absence to pragmatic involvement (Navarro 2012; Brack 2012, 2013). Such MEPs face a tension between gaining finance and publicity via the EP and avoiding the impression of accepting the legitimacy of the institution. As indicated in the discussion of the ECR above, soft Eurosceptics, by contrast, are more likely to attempt to achieve influence in the legislative process. Both types of party are represented in the EFD such that we expect to see differences in approach to the EP's activities within the group.

The EP's Legislative Observatory shows that the EFD were under-represented in the distribution of reports in the first 3.5 years of the seventh term, gaining around 2 per cent of 
these. If we look at the 17 reports taken on by EFD MEPs in the responsible committee in this period, differences between national parties are clear. 12 of these were written by MEPs from just two parties, the Lega Nord (7) and LAOS (5). UKIP took on one report, in the hands of Marta Andreasen on the Budgetary Control committee. Andreasen defected to the Conservatives and ECR group in February 2013. EFD reports are therefore distributed disproportionately within the group, with little role for UKIP in this area of activity. EFD officials indicated the group takes a pragmatic approach to this: 'We try to influence legislation and to diminish its harmful effects or to block it'. ${ }^{25}$ Referring to UKIP, another explained with regard to amendments, 'If something is in line with our outlook, [the MEP] should vote yes, such as with amendments that delete text and make policy more free market. It is rare in committee that [we] produce an entirely negative voting list ${ }^{2}{ }^{26}$ Officials and MEPs indicated that UKIP also proposes amendments in committee where they feel this will further their aims. Interviewees suggested the group does not normally engage in coalitionbuilding but indicated that the EFD may respond by supporting actions taken by others, including Eurosceptics on the left and libertarian parties such as the Swedish Pirate Party, when they are in agreement.

If we look in more detail at other activities in the EP, based on data adapted from VoteWatch Europe ${ }^{27}$ differences within the group are clear. For instance, the mean attendance at plenary sessions in the seventh term up to March 2013 was 76 per cent for UKIP MEPs and 92 per cent for those in the Lega Nord. We see similar variations on other measures. In the same time period, UKIP MEPs asked an average of 101 questions each, while the figure for the LN was 359. A similar gap is evident in the numbers of reports amended, which, for the average UKIP MEP is four compared with 76 for those in the Lega Nord. In addition the mean numbers of motions for resolution signed by MEPs are respectively 0.7 and 33 . While we would expect some differences in these measures between national parties in any group, the variations among ECR parties are much smaller, with mean attendance levels hardly varying at all from one national contingent to another and an overall mean attendance of 87 per cent. Indeed, UK Conservative MEPs sometimes criticise their UKIP counterparts for nonattendance at votes. Intragroup differences in the EFD suggest that its national parties differ in their views about how to operate in the European Parliament and what the group is for. LN and other non-UKIP MEPs in the group appear to be engaging to some degree with the options open to MEPs to attempt to influence the EP's outputs. UKIP MEPs involve themselves much less in these activities, a difference acknowledged by EFD group staff in 
interviews. ${ }^{28}$ These findings are consistent with our expectations on the basis of the different types of Euroscepticism associated with these parties and the likely effects of this on their policy-seeking behaviour.

\section{Conclusion}

Using interviews, roll-call voting data, expert judgements, information on MEPs' activities and some brief legislative case studies, this paper has demonstrated the different approaches that Eurosceptic parties and groups take to operating within the EP. These differences, with regard to group formation, cohesion and engagement with EP activities make sense in terms of variations in Euroscepticism and the presence of niche parties in the EFD group. Returning to our theoretical framework based on Strøm (1990) and others, we have seen that, especially for the UK Conservatives, the ECR's formation represents a sometimes uneasy mixture of policy-seeking and party management aims, rather than office- and vote-seeking. For UKIP, the EFD group was formed largely on the basis of distinctive practical advantages, such as speaking time in plenary for publicity more than policy, and resources for political campaigns rather than mainly for attempting to influence legislation. These differ somewhat from the pragmatic motivations that Bressanelli (2012) refers to among mainstream groups, as they are about seeking publicity more than policy influence in the EP and they concern resources for extra-EP campaigning.

The different motivations for group formation are reflected in differences between the groups' cohesion. The ECR is largely cohesive in roll-call votes and has a level of ideological diversity that compares favourably with others. By contrast, views within the EFD are wideranging on the EU integration dimension, although its diversity is comparatively limited in left-right terms. As we expected on the basis of two types of niche party being represented in the group, there is no group whip and voting cohesion in roll-call votes is low on distributional policies as well as in the examples of market regulation and EU integration issues we considered here. This effect of niche parties seems to be specific to the presence of hard Eurosceptics and regionalists in the same group as we observed high cohesion in rollcall votes in the G/EFA.

While it would be wrong to suggest that the EFD is entirely disengaged from the EP's activities, it is hard to speak of this group as an individual actor as its two largest parties take 
rather different approaches. This is consistent with our suggestion that policy-seeking behaviour in the EP will vary by type of Euroscepticism. The soft Eurosceptic ECR group engages much more with the EP's work and - as we saw through examples of Conservative MEPs' activities - attempts to influence policy outcomes by coalition-building and trying to set the agenda for forthcoming proposals in some areas. But when it comes to policy influence, numbers matter in the European Parliament. The comparatively small size of the ECR combined with its stance on European integration, which differs from that of the largest three party groups, mean that there are many areas in which it finds itself on the losing side.

The existence of the ECR means that party competition in the EP now involves a coherent soft Eurosceptic group made up partly of governing parties, which attempts to influence policy but which is limited by being only the fifth largest group. The basis of the group as primarily Eurosceptic and its relative cohesion on this make it different from the UEN. The presence of a hard Eurosceptic co-leader of the EFD group also means that there is now a voice in the EP's Conference of Presidents and at the EP's high profile plenary sessions arguing against the entire integration project. With hard and soft Eurosceptic views present via the leadership of EP groups, we may be seeing better representation of these stances via Europe's parliament. Whether voters are aware of the very different approaches taken to the EP by hard and soft Eurosceptic MEPs is less clear and requires further research.

Looking ahead to the situation after the 2014 European elections, the ECR seems likely to remain in place but its chances of growing substantially would appear to be slim. Cameron's veto in 2011 and the group leadership style of Martin Callanan, who has tended to differ from the Conservative leadership on some issues - he called for Greece to leave the Euro for instance - may make it more difficult for the ECR to gain parties currently in the EPP and ALDE. The group will therefore have to continue attempting influence via some of the approaches set out here. While some of its new MEPs either arrived with or have begun to develop policy expertise, several of the Conservatives' most experienced members have chosen not to stand in 2014 including Atkins, Chichester, Harbour, Stevenson and Sturdy. Their replacements, if elected, will need to quickly learn how to operate in the EP if the group is to continue trying to influence policy through specialism in particular areas. Both the ECR and EFD are vulnerable due to the number of single representatives of member states in these groups. This means their future composition, and survival in the case of the smaller EFD, is dependent upon how these very small parties perform in 2014. While it seems likely 
that UKIP and the Lega Nord will be present in reasonable numbers, it is difficult to predict with certainty the other members of any future group they develop. Should there be higher numbers of Eurosceptic MEPs after the 2014 ballot, the decisions that Eurosceptics have to make about group choice and how to approach the EP, highlighted in this paper, may become even more significant.

${ }^{1}$ Interview with Conservative MEP, 20/12/10.

${ }^{2}$ The data are available at http://www.essex.ac.uk/bes/.

${ }^{3}$ These data are available at http://www.bes2009-10.org/.

${ }^{4}$ Interview with Conservative MEP, 11/11/09.

${ }^{5}$ Interview with UKIP MEP, 23/09/09.

${ }^{6}$ Interview with UKIP staff, 17/08/09.

${ }^{7}$ Interview with EFD group staff, 28/09/10.

${ }^{8}$ Interview with UKIP MEP, 23/09/09.

${ }^{9}$ Interview with UKIP MEP, 10/11/11.

${ }^{10}$ Nattrass rejoined the EFD in December 2012.

${ }^{11}$ The two exceptions are the Luxembourg Christian Social People's Party (part of the EPP group), which has three MEPs, and the Maltese Labour Party (part of the S\&D group), which has four.

${ }^{12}$ In the Chapel Hill 2010 data, the left-right dimension is measured on an 11 point scale whereas the scale for the EU dimension has seven points. We therefore converted the EU dimension scores to an 11 point scale to ensure comparability of the two measures.

${ }^{13}$ Interview with UKIP MEP, 10/11/11.

${ }^{14}$ These scores are available at: http://www.votewatch.eu/en/political-group-cohesion.html

${ }^{15}$ Interview with EFD group staff, 08/11/11.

${ }^{16}$ Interview with EFD group staff, 28/09/10.

${ }^{17}$ Analysis of coalition patterns among national parties across the two groups shows that the Conservatives vote more frequently with these four parties than do UKIP.

${ }^{18}$ Interview with Conservative MEP, 9/11/11. Other ECR group staff and MEPs made very similar points.

${ }^{19}$ Reports are referred to here by their EP procedure file code.

${ }^{20}$ Interviews with ECR group staff, 9/11/11 and 28/11/12.

${ }^{21}$ At the time of writing this was the stage reached in the legislative process. 
${ }^{22}$ Interview with ECR group staff, 9/11/11.

${ }^{23}$ Interview with ECR group staff, 28/11/12.

${ }^{24}$ Interview with Conservative MEP, 11/11/09.

${ }^{25}$ Interview with EFD group staff, 28/09/10.

${ }^{26}$ Interview with EFD group staff, 10/11/11.

${ }^{27}$ These data are available at: http://www.votewatch.eu/en/activity-statistics.html

${ }^{28}$ Interview with EFD group staff, 28/09/10. 


\section{References}

Adams, J., Clark M., Ezrow, L. and Glasgow, G. (2006) 'Are Niche Parties Fundamentally Different from Mainstream Parties? The Causes and the Electoral Consequences of Western European Parties' Policy Shifts, 1976-1998', American Journal of Political Science, 50(3): 513-29.

Bakker, R. de Vries, C., Edwards, E., Hooghe, L., Jolly, S., Marks, G., Polk, J., Rovny, J., Steenbergen, M., Vachudova, M. (2012) 'Measuring party positions in Europe: The Chapel Hill expert survey trend file, 1999-2010', Party Politics, OnlineFirst, doi: $10.1177 / 1354068812462931$.

Bale, T., Hanley, S. and Szczerbiak, A. (2010) "'May Contain Nuts"? The Reality behind the Rhetoric Surrounding the British Conservatives' New Group in the European Parliament', Political Quarterly, 81(1): 85-98.

Bartlett, J. Birdwell, J. and McDonnell, D. (2012) Populism in Europe: Lega Nord (London: Demos).

Benedetto, G. (2008) 'Explaining the failure of Euroscepticism in the European Parliament' in Taggart, P. and Szczerbiak, A. (eds) Opposing Europe: The Comparative Party Politics of Euroscepticism, Volume 2: Comparative and Theoretical Perspectives (Oxford: Oxford University Press): 127-50.

Brack, N. (2012) 'Eurosceptics in the European Parliament: Exit or Voice?', Journal of European Integration, 34(2): 151-68.

(2013) 'Euroscepticism at the Supranational Level: The Case of the 'Untidy Right' in the European Parliament', Journal of Common Market Studies, 51(1), pp.85-104.

Bressanelli, E. (2012) 'National parties and group membership in the European Parliament: ideology or pragmatism?', Journal of European Public Policy, 19(5): 737-54.

EurActiv (2009) 'Tories lose Finn, Greens gain Swedish pirate', 26 June, euractiv.com/euelections/tories-lose-finn-greens-gain-swedish-pirate/article-183513.

(2012) 'MEPs approve ban on ultrafast trading', EurActiv, 29 October, euractiv.com/euro-finance/meps-green-light-ban-ultrafast-t-news-515711.

Ezrow, L., de Vries, C., Steenbergen, M. and Edwards, E. (2011) 'Mean Voter Representation and Partisan Constituency Representation: Do Parties Respond to the Mean Voter Position or to their Supporters?', Party Politics, 17(3): 275-301.

Hanley, D. (2008) Beyond the Nation State: Parties in the Era of European Integration (Basingstoke: Palgrave).

Hix, S., Noury, A. and Roland, G. (2005) 'Power to the Parties: Cohesion and Competition in the European Parliament, 1979-2001', British Journal of Political Science, 35(2): 209-234. 
— (2007) Democratic Politics in the European Parliament (Cambridge: Cambridge University Press).

Independent (2009) 'David Cameron: I'll pull the plug on Brown', The Independent, 10 May.

Jensen, C. and Spoon, J-J. (2010) 'Thinking locally, acting supranationally: Niche party behaviour in the European Parliament', European Journal of Political Research, 49(2): 174201.

Maurer, A., Parkes, R. and Wagner, M. (2008) 'Explaining group membership in the European Parliament: The British Conservatives and the Movement for European Reform', Journal of European Public Policy, 15(2): 246-62.

McElroy, G. and Benoit, K. (2010) 'Party Policy and Group Affiliation in the European Parliament', British Journal of Political Science, 40(2): 377-98.

(2011) 'Policy positioning in the European Parliament', European Union Politics, 13(1): $150-67$.

Müller, W. and Strøm, K. (1999) 'Political Parties and Hard Choices' in W. Müller and K. Strøm (eds.) Policy, Office or Votes? How Political Parties in Western Europe Make Hard Decisions (Cambridge: Cambridge University Press): 1-35.

Navarro, J. (2012) 'The cognitive rationality of role choices: Evidence from the European Parliament' in M. Blomgren and O. Rozenberg (eds) Parliamentary Roles in Modern Legislatures (London: Routledge): 184-210.

O'Hara, M. (2011) 'European Regulation, High Frequency Trading and the Draft MiFID Review: An Interview with Dr Kay Swinburne MEP', The High Frequency Trading Review, $\mathrm{hftreview.com} / \mathrm{pg} / \mathrm{blog} / \mathrm{mike} / \mathrm{read} / 5355 /$ european-regulation-high-frequency-trading-and-thedraft-mifid-review.

Petitjean, S. (2010) 'Impact study on maternity leave eagerly awaited', Europolitics, 25 March, europolitics.info/impact-study-on-maternity-leave-eagerly-awaited-artr26727825.html.

Spicer, J. (2010) 'The 20 minute "flash crash" will reverberate for quite some time to come', Reuters, 15 October, reuters.com/article/2010/10/15/us-flashcrash-europeidUSTRE69E1Q520101015.

Stamatoukou, E. (2013) 'MEPs: Professional electronic card will ease mobility in EU', New Europe Online, 24 January, neurope.eu/article/meps-professional-electronic-card-will-easemobility-eu.

Startin, N. (2010) 'Where to for the Radical Right in the European Parliament? The Rise and Fall of Transnational Political Cooperation', Perspectives on European Politics and Society, 11(4): 429-49.

Strøm, K. (1990) 'A behavioral theory of competitive political parties', American Journal of Political Science, 34(2): 565-98. 
Taggart, P. and Szczerbiack, A. (2008) 'Theorising Party-Based Euroscepticism: Problems of Definition, Measurement and Causality' in P. Taggart and A. Szczerbiack (eds) Opposing Europe. The Comparative Party Politics of Euroscepticism, Volume 2 (Oxford: Oxford University Press): 238-62.

Wagner, M. (2012) 'Defining and Measuring Niche Parties', Party Politics, 18(6): 845-64.

Webb, P. (2000) The Modern British Party System (London: Sage). 
Table 1 Ideological diversity in EP party groups

\begin{tabular}{|c|c|c|c|}
\hline Party group & $\begin{array}{c}\text { Ideological diversity on } \\
\text { left-right scale }\end{array}$ & $\begin{array}{c}\text { Ideological diversity on } \\
\text { EU scale }\end{array}$ & $\begin{array}{c}\text { Number of parties used } \\
\text { in calculation }\end{array}$ \\
\hline European People's Party & 0.64 & 0.92 & 35 \\
\hline Socialists and Democrats & 0.40 & 0.72 & 26 \\
\hline $\begin{array}{l}\text { Alliance of Liberals and } \\
\text { Democrats for Europe }\end{array}$ & 0.94 & 0.64 & 24 \\
\hline $\begin{array}{l}\text { Greens/European Free } \\
\text { Alliance }\end{array}$ & 0.69 & 0.97 & 16 \\
\hline $\begin{array}{l}\text { European Conservatives } \\
\text { and Reformists }\end{array}$ & 0.42 & 0.83 & 7 \\
\hline United European Left & 0.26 & 1.01 & 12 \\
\hline $\begin{array}{l}\text { Europe of Freedom and } \\
\text { Democracy }\end{array}$ & 0.60 & 1.55 & 9 \\
\hline
\end{tabular}

Note: the maximum value this measure can attain varies with the scale on which political positions are measured. This means we cannot directly compare these figures with those in Hix et al. (2005) where Comparative Manifesto Project data were used to measure party positions.

Table 2 Coalition patterns in roll-call votes among national parties in the EFD group, July 2009 December 2010

\begin{tabular}{lccccccc}
\hline & $\begin{array}{c}\text { Lega } \\
\text { Nord }\end{array}$ & UKIP & LAOS & $\begin{array}{c}\text { Order \& } \\
\text { Justice }\end{array}$ & $\begin{array}{c}\text { True } \\
\text { Finns }\end{array}$ & MPF & $\begin{array}{c}\text { Slovak National } \\
\text { Party }\end{array}$ \\
\hline Lega Nord & - & 32.4 & 70.4 & 54.0 & 61.1 & & \\
UKIP & 32.4 & - & 22.5 & 18.2 & 42.5 & & \\
LAOS & 70.4 & 22.5 & - & 56.4 & 52.2 & & \\
Order \& Justice & 54.0 & 18.2 & 56.4 & - & 43.5 & & \\
True Finns & 61.1 & 42.5 & 52.2 & 43.5 & - & & \\
MPF & 36.9 & 51.6 & 29.8 & 19.4 & 46.9 & - & - \\
Slovak National Party & 66.9 & 32.2 & 60.6 & 54.4 & 61.7 & 35.4 & 54.5 \\
Danish People's Party & 53.6 & 43.9 & 49.8 & 41.3 & 57.9 & 42.4 & 14.2 \\
Reformed Political & 16.4 & 42.5 & 14.7 & 18.7 & 19.1 & 32.9 & \\
Party & & & & & & & \\
\hline
\end{tabular}

Abbreviations: LAOS: Popular Orthodox Rally, MPF: Mouvement pour la France, UKIP: UK Independence Party 
Table 3 Coalition patterns in roll-call votes among national parties in the ECR group, July 2009 December 2010

\begin{tabular}{lccccccc}
\hline & $\begin{array}{c}\text { List } \\
\text { Dedecker }\end{array}$ & $\begin{array}{c}\text { Civic } \\
\text { Democrats }\end{array}$ & $\begin{array}{c}\text { Hungarian } \\
\text { Democratic } \\
\text { Forum }\end{array}$ & ChristenUnie & TB/LNNK & $\begin{array}{c}\text { Poles in } \\
\text { Lithuania }\end{array}$ & $\begin{array}{c}\text { Law and } \\
\text { Justice }\end{array}$ \\
\hline List Dedecker & - & 89.4 & 95.3 & 91.0 & 88.4 & & \\
Civic Democrats & 89.4 & - & 92.2 & 85.3 & 88.7 & \\
$\begin{array}{l}\text { Hungarian } \\
\text { Democratic }\end{array}$ & 95.3 & 92.2 & - & 89.6 & 93.0 & & \\
Forum & & & & & & & \\
ChristenUnie & 91.0 & 85.3 & 89.6 & - & 84.8 & & \\
TB/LNNK & 88.4 & 88.7 & 93.0 & 84.8 & - & & \\
Poles in & 87.7 & 87.8 & 91.9 & 85.9 & 91.6 & & \\
Lithuania & & & & & & & \\
Law and Justice & 87.0 & 86.7 & 90.4 & 84.7 & 90.1 & 95.6 & 85.0 \\
Conservatives & 90.1 & 89.3 & 92.4 & 84.2 & 87.1 & 85.2 & \\
\hline
\end{tabular}

Abbreviation: TB/LNNK - Latvian National Independence Movement/For Fatherland and Freedom 